Kohl: a Journal for Body and Gender Research

Vol. 6, No. 1 (Summer 2020)

\title{
Attempting to Organize a Syrian Feminist Movement: War, Exile, and Intergenerational Tensions
}

Rula Asad 
This article is a predicament. Physically, writing it caused me numerous stomachaches and headaches.

Psychologically, it made me doubt my positionality towards the subject matter and my entitlement to write about it. I then realized that it was not the first time that I find myself so involved.

Since I decided to contribute to this issue devoted to "Tensions in Movement Building," I began searching for diplomatic, indirect, twisted, witty ways to raise the issue of tensions within our feminist/women's movement, for one of our problems is the avoidance of confrontation.

When I returned to the journalistic and academic archives of the feminist/women's movement in Syria, I could not find much on the movement's paths and forms of organizing. Instead, they were treated as annex to related causes. From my position as an activist in the feminist movement, I now better understand why it is the case.

The contexts of the movement are difficult to navigate, particularly when determining the kinds of conflicts that emerge within it. It is even more difficult to talk about these conflicts without creating rifts and without my intervention being understood as an attack.

I am preoccupied with the question of my positionality and that of the comrades in the movement in the general feminist/women's context. For several years now, I have had direct conversations with friends, held on the sidelines of conferences and meetings to which I was invited to as the director of "Syrian Journalists Network" and/or as a journalist, to pose questions that concern us. Who are we as feminists? Can we differentiate between our ideologies and the schools to which we belong? Are we a wave that encompasses a large group of people who have nothing but that cause in common, and hence move in an organized but decentralized way? Or are we rather a movement predicated on organizing its members and that advances according to specific agendas? Or are we a more organizationally spontaneous movement: numerous, diverse, and bound by a broad theme, but without agreement on how to organize ourselves? Does our movement circumvent the organizing in networks and organizations in favor of less administrative fatigue and more freedom? Are we, therefore, consciously moving away from branding our work, struggle, and activism as a "movement," due to the organizational consequences?

\section{The Diaspora and its Geography}

Initially, in an attempt to escape writing, I wanted to converse with some of the leading young feminists in feminist/women's organizations. But this was difficult to accomplish: each one of us was residing in a different country. Here, we confront diaspora. As a young, still rising Syrian movement composed of feminists in their 30s and 40s from a multitude of social, religious, national, and economic backgrounds, we practiced our feminist activism in tandem with our involvement in the peaceful revolutionary movement. Geography stands as a considerable barrier to meeting in person, and we try to use the international events that we participate in to exchange ideas and start feminist discussions. But we then fall into the traps of representation and attendance, inquiring about who was invited; why a given topic was discussed and not others; and who 
decided to put it forward as a priority. We become silently angry at our exploitation as activists as we fulfill consultative assignments, prepare research, and present ten-minute presentations on violence, political participation, and conflict, all as free labor. We accept this and we endure the long working hours in the hope that these ten minutes will contribute, first, in preventing what is happening in Syria from being forgotten and perhaps second, in promoting such institutions and increasing their opportunities to receive support.

As a Syrian movement, we face an impossible task in a context that could not be more complicated. In the 2011 Revolution, this movement escaped the authority's kidnappings and grasp and found a way to break through regionalism and elitism. However, the peaceful civil movement did not sufficient time to allow for its values and methods to be engrained, for soon after its emergence, the revolution took on the form of armed struggle. And, as with any armed struggle - in which no sound is louder than that of battle - those who carried the weapons determined the priorities of the moment, until this day. As for us women, we were told that our struggle could wait. The conflict became a routine, normal daily reality. Despair killed us and we spread across the diaspora. Many feminist initiatives, particularly inside Syria, were unable to last long enough to accumulate experience in their areas, for the increasing violence and the targeting of women activists forced them to temporarily flee to neighboring countries. Lebanon and Turkey were the main destinations for many activists, but the political context in both countries, however different, prevented activists from working freely. In Lebanon, for instance, activists were banned from civil work without a license, which are not easily obtainable. Some organizations only have to submit a public notice to the Ministry of Interior to work, but this does not protect their work from being terminated at any time. All of these difficulties are compounded with the existing racism against Syrian presence in Lebanon.

The conditions in Turkey are no better. In the beginning of 2012, the Turkish government allowed many organizations from the Syrian civil society to work without a permit and even without question. However, since 2016, restrictions began and activists were held accountable for their work in previous years. The Turkish authorities also intimidated these organizations by paying them surprise visits, putting the activists and workers in the organizations under pressure and surveillance. Thus, in the years to come, activists would leave for Europe, the United States, and Australia, most with no hope to return to or work freely in the region.

Diaspora and geography confront us and drain our energy as we travel long hours and as our patience is tested at border crossings and airports. We exert great effort to overcome the distance between us when we meet, to become close even if just superficially and temporarily, and to discuss, during our coffee breaks, the latest developments or, perhaps, to reassure ourselves that we remain united in our battle. And yet, we are constantly faced with social media campaigns that accuse activists of monopolizing conference spaces and not working to bring forth new voices. Feminists bear all these burdens, while the critics forget that activists do not control the issuance of travel visas to participate in conferences. Is the same critique ever directed towards the male activists? Furthermore, are women activist expected to leave their seats empty when others are unable to participate due to travel restrictions? Many Syrian feminist initiatives have employed the tactic of "empty chairs" as a means of resisting the marginalizing discourse against women, and as a way of rejecting the pretext that there are no women who are experts in some of the presented topics. Hence, the 
tactic of "empty chairs" represents, for some, a symbolic response to men occupying most of the discussion seats at conferences and forums.

\section{Organizing in the Context of No War, War, and Exile}

Marcell Shehwaro, ${ }^{1}$ a human rights activist and blogger from Aleppo who now resides in Turkey, says that "the fundamental difference between our movement and the movement of the older generation is that they were more organized." This analysis is quite realistic: most of the earlier activists were members of political parties - most famously, the Communist Labour Party. Their partisan experience helped them, at least, in organizing actions as political actors, activists, and women's rights advocates, while my generation of feminists (those in their 30s and 40s) is considered young and currently accumulating experience. Likewise, my generation organized its activity and its involvement in public affairs and within the Syrian context since 2011 in a space shaped by the young Syrian civil society and in difficult, highly politicized political and economic regional contexts.

"In conditions of war, it is difficult to speak of an organizational form. The difference in the organizational form of the older generation of feminists that Marcell mentioned must be understood in the context of no war and no funding. Today, most platforms and initiatives are dependent on funding. This is not intended as an absolute criticism, but rather as an attempt to point out that efforts and initiatives are advanced in the form of specific projects," says Maria Al-Abdeh, director of Al-Nisa 'Al-Ann ("Women Now"), emphasizing the repercussions of this in limiting experimentation and free production and in being submerged under the requirements of administrative matters.

In the shadow of war, political participation often becomes entangled in responses to emergency events and basic humanitarian needs.

The involvement of feminists in civil society institutions is not limited to forming and working within women's institutions and organizations. Their work overlaps with transitional justice and accountability, freedom of speech, press, education, health care, politics, etc. However, due to overwhelming administrative duties and concerns over the survival of these institutions, the toll of institutional involvement implies losing the opportunity to contribute to feminist knowledge production. In addition, organizing through these institutions may be subjected to a form of domestication with regards to what issues are considered appropriate or inappropriate. Institutions operating outside the national borders escape governmental domestication but are compelled by the capitalist structure to work in particular ways in order to obtain funding and to survive. Due to the lack of time, energy, and spaces for serious discussions, these preoccupations diminish the opportunities to form, organize, and theorize a clearly defined feminist movement.

\footnotetext{
${ }^{1}$ https://www.activisthive.org/marcell-shehwaro/
} 


\section{The generational issue and the elitism of the previous wave}

The diaspora and the lack of organization are not the only obstacles that we face. Rather, there are neverending explicit and implicit conflicts and tensions, the generational issue being the most important one. Most liberation waves in the region are temporally out of sync with global waves due to the colonial campaigns, which lasted until the 40s and 50s and resulted in the kinds of regimes established in colonized countries. Consequently, in most of these countries (including Syria), established totalitarian regimes exploited the issue of rights, particularly women's rights, to endow the state with some aspects of civility. Thus, our local feminist waves are not equivalent to the universally recognized waves.

When addressing the older feminists, I become nervous as I want to point out the differences in our feminist outlooks. It further prevents me from naming our political and age differences and acknowledging the efforts and achievements of feminists of every generation, particularly ours, in a harrowing historical and political period.

For me, the generational issue is a problem of narrative: first, it prevents us from starting a real and deep discussion about the movement and its internal dimensions, whether social and cultural or relating to age, gender, and sex. Second, all prioritized issues for discussion and struggle are in fact related to age. The generation of "veteran feminists" includes middle-class women whose political activity was predominantly in the 70s and 80s. They live in or are from large cities, and come from secular or, at least, religiously openminded families. This makes sense when we look at which activities were permitted and who was allowed to practice them within the political context of Syria under the Ba'ath regime. Until today, some of them consider that feminist action and the fight for women's rights and freedoms must begin from the principle of helping the poor, eradicating poverty, and liberating poor and rural women from their "ignorance."

In all the directions of our feminist paths, the elitism of feminist/women's activity in Syria will always stand as a rigid glass panel: transparent yet hard to penetrate or shatter. The reason for this is the long and eventful history of the "veterans," many of whom have endured prison; they agree, explicitly and implicitly, on prioritizing their engagement in direct traditional political action and their protracted struggle to end violence against women both legally and socially. In addition, their attempts to change the status quo through confronting the authorities before 2011 have contributed to strengthening the bonds between them to such an extent that it makes it difficult to penetrate or even to welcome newcomers in their ranks.

Confining feminist struggle in the defense of women's rights constitutes a point of difference between the younger and older generations. Today's activists believe that the struggle must target the root cause, namely the patriarchal system that interferes in our daily lives, both personal and public, based on the principle that the personal is also and always public and political.

I cannot but see the generational issue within the movement through the vantage point of war and, afterwards, of exile as the two principal events in forging ties. My generation witnessed the revolution, the war, and exile, and in these three contexts, small, interconnected networks based on trust must be built. Considering 
everything outside these networks as suspicious and as associated with perilous feelings may somewhat explain our exclusiveness and our inability to forge real ties with the previous generation, as well as our attempts to avoid repeating the pattern of mistrust and intimidation with the next generation.

\section{The Syrian Women's Advisory Board as an imposed experiment}

If the last eight years were to be reduced to a single event, it would be the formation of the Women's Advisory Board in 2016, a body attached to the political negotiations that provides advisory support in gender affairs to the special envoy of the United Nations for Syria, which was a wound in the internal Syrian feminist movement. While the United Nations ${ }^{2}$ and the European and American governments that supported the establishment of the board considered it an unprecedented achievement, I find this characterization a cunning justification to the failure of the United Nations to ensure the presence of women at the negotiating table.

During the first press conference of the board in Geneva in 2016, the women members of the board demanded an "immediate relief of economic sanctions on the Syrian people that impede the arrival of food, medicine, and medical equipment." A large number of women's groups angrily objected to the announcement because it was interpreted as a call to ease sanctions on Bashar al-Assad's regime - the first lethal trap the board fell into. Certainly, campaigns expressing "the women of the Advisory Board do not represent me," particularly those concentrated on defaming the members of the board, are completely unacceptable and unjustified, as are the defamatory and libelous attempts of some campaigners to mobilize the masses to question the seriousness and patriotism of many of the board members. Thus, from day one, the members paid a high price for their work, which has undermined the reputation of the board since its announcement.

Through the establishment of the Women's Advisory Board, the struggles of Syrian women's groups were reduced to a traditional, quasi-political body, and the board became the principal and final reference for any issue related to the Syrian feminist movement. My main disagreement with the board concerns the way in which it was formed, the role it was assigned, and how it was presented as an "achievement." Not only has the United Nations failed to steer the negotiating parties towards reconciliations, truces, and prisoners exchange, but it was also unable to enforce a quota for the representation of women on the negotiations table, which is recognized by feminist women to be $30 \%{ }^{3}$ at a minimum. Instead, it formed a peripheral board whose tasks are confined to providing counsel to the Office of the UN Special Envoy.

The members of the board, who are feminist activists and decade-long defenders of human and women's rights, fell into the traps of representation and of the process of ratification. They accepted the offered representation instead of developing a discourse that addresses the impossibility of representation in the

\footnotetext{
2 https://www.unwomen.org/en/news/stories/2016/2/ed-statement-on-syrian-womens-advisory-board

${ }^{3}$ https://www.unescwa.org/sites/www.unescwa.org/files/publications/files/women-political-representation-arab-regionarabic.pdf
} 
current Syrian situation. As such, they defended and legitimized the board, as it was keen to include women from different political, religious, and regional backgrounds with the pretext of representing women at home and abroad according to their involvement in numerous women's blocs, alliances, networks, and organizations. However, this did not convince the enraged masses, particularly since the issue of representation remains a thorny one for Syrians after years of invisibility, totalitarianism, and exclusion under the rule of "the Ba'ath." Nevertheless, with time, the board was able to overcome these difficulties by insisting that its members only represent themselves, as well as the groups to which they belong, and not the Syrian feminist movement as a whole, given that the movement lacks clarity in its structure, organizational form, and priorities.

As for the trap of the process of ratification, the board was established by international decision and was built on the ruins of the "Syrian Women for Peace and Democracy" initiative. Its founding mechanisms were marred by mystery and a lack of transparency, as reported by members of the initiative, which fills me with resentment and anger. Most depressing of all, the United Nations views this experiment as unique, and there is even a tendency to replicate it in Libya and Yemen, while there are still no procedural mechanisms for the aforementioned board. Only the United Nations has evaluated the experiment as "successful" while, locally, we had no opportunity to critically assess this experience and rethink it before it is exported.

The main problem with the board is the mismatch between its advertisement and its reality. In the first press conference in Geneva in 2016, it was said that the Women Advisory Board (WAB) was established "in response to the demands of Syrian women in order for them to have an active role in the political process and to shape the contours of the future of Syria." This contradicts what most of the activists say, namely, that the establishment of the board proceeded without an open call and was rather limited to the women involved and the supporting international entities. This state of affairs is not limited to the WAB and recalls precedents of Syrian opposition experiments that have created new organizations that hold within them old organizations or that are built on their ruins or their exclusion.

To further exemplify this, the Women's Advisory Board was established by gathering a number of women simply on the basis that they are women - who provide advice to the UN envoy and are presented as "peace advocates," regardless of existing political tensions and their tendency for neutrality, which further strips them of their backgrounds and their political views and positions. This was recorded in the statement of the feminist lobby at the time. ${ }^{4}$ In 2016, Rim Turkmani, one of the board members, wrote on Facebook: "this board is not a negotiating party; it does not hold any representational status; its work is voluntary; and none of its members receive any form of monetary compensation." This statement in itself suffices to explain the United Nations' perspective, and behind it, that of the "white" governments, on the role that local women can play in Syria during times of conflict and beyond. Stereotyping women, despite all the efforts that activists have made at the local level, is further deepened by international efforts under the pretext of supporting political participation. This participation is often under a ceiling imposed by the residue of dictatorships and armsbearers in meetings cloaked under, for instance, the title of "peace negotiations."

${ }^{4}$ http://musawasyr.org/?p=15880 


\section{Issues that have yet to be thought through}

If we had the time to think deeper about our movement, we would have found, at least, that we are not yet in agreement on, for instance, whether the movement is a feminist or a women's movement. Indeed, the Syrian movement is largely limited to defending women's rights, particularly in ending violence and in political action, whereas sexuality, gender, queerness, masculinity, and femininity remain secondary issues for discussion and publicly defending them remains shameful. Despite that, there are other small feminist and women's movements and individuals within the movement that carry these causes and publicly defend them despite attempts to undermine and ridicule them.

As for the absence of organized communication and interaction within the movement at the level of institutions, initiatives, and even individuals, it is due to the predominant hierarchical structure of public work and the hindrances to achieving a sustainable organizational structure, in addition to the restrictive geographic distance and the dependence on online communication, which is often exhausting. All of these aspects result in doubts of the internal movement, which does not receive sufficient support from the external movement, and which does not believe that it is fulfilling its obligation - that is, to convey the voices of the internal movement. In addition to its lack of organization, what is tiring about this form of communication is its shortsightedness, as it is limited to executing only one common project.

It is not possible to speak of any civic engagement from exile or in the context of an armed struggle without considering the form and conditions of its financial support. Experts and activists alike are aware of the ambivalence of international funding, with opinions ranging from viewing it as coopting, to viewing it as a catalyst for new collaborative or mediating opportunities. Still, and more often than not, international funds come with predetermined purposes, set by the donors themselves. Often, participants find themselves entangled in agendas that have high expectations, for instance, expecting them to participate by bringing forth their experiences as witnesses and narrators, and not as experts in their respective fields.

International feminist NGOs somewhat relieve us from these demands. They provide us with a margin of freedom through the funds that we receive and with an opportunity to support local efforts in empowering feminist institutions and linking them with transnational experiences. However, many international institutions that are interested in supporting women contribute to stereotyping them in specific fields of work and overwhelming them with administrative duties.

Exhaustion is a shared characteristic in our movement. Reducing our expertise, opinions, and positions into narrations of our personal stories in front of dozens and hundreds of people so as to draw attention to the calamities taking place in Syria has exhausted us all and has psychologically destroyed many of us. We open our wounds, in front of a live audience and our eyes widen, resisting collapse and the moment of shedding tears that everyone waits for - we, the "oriental women coming from a war-zone." But we don't cry; we hold 
46 our breath, resist the stereotypes, and the invasion of our personal lives, and insist on doing what we ought to do.

I feel frustrated whenever I ruminate about our daily preoccupations. I remember my anger at the lack of archives, the experiences of the Syrian feminist movement before 2011, and the lack of openness that kept us from joining the movement early on. I find that we are repeating the same mistakes: exclusion, cronyism, failing to create safe spaces, holding others responsible for the collapse of their careers and their withdrawal from the public sphere, personalizing common causes, burdening them with personal conflicts, etc. However, I am also aware that we have been forced to become immigrants, migrants, displaced women, and refugees, struggling in new, changing regional and international contexts that are often unwelcoming. Every time I review this article, I think about what we are preoccupied with today and how we are led to be distracted in the midst of tensions, conflicts, and institutional duties that stifle creativity and energy and destroy all forms of solidarity. 